Gene Flow between Breeding Populations of Lesser Snow Geese

Author(s): F. Cooke, C. D. MacInnes, J. P. Prevett

Reviewed work(s):

Source: The Auk, Vol. 92, No. 3 (Jul., 1975), pp. 493-510

Published by: University of California Press on behalf of the American Ornithologists' Union

Stable URL: http://www.jstor.org/stable/4084603

Accessed: 09/04/2012 16:59

Your use of the JSTOR archive indicates your acceptance of the Terms \& Conditions of Use, available at http://www.jstor.org/page/info/about/policies/terms.jsp

JSTOR is a not-for-profit service that helps scholars, researchers, and students discover, use, and build upon a wide range of content in a trusted digital archive. We use information technology and tools to increase productivity and facilitate new forms of scholarship. For more information about JSTOR, please contact support@jstor.org. 


\title{
GENE FLOW BETWEEN BREEDING POPULATIONS OF LESSER SNOW GEESE
}

\author{
F. Cooke, C. D. Macinnes, and J. P. Prevett
}

THE measurement of gene flow between natural populations of animals in the field has rarely been achieved in population biology. The nesting colonies of Lesser Snow Geese (Chen c. caerulescens) in the Hudson Bay area provide a favorable situation for such measurements-they are relatively discrete, often separated by hundreds of miles (Fig. 1), and, at many of the colonies, large numbers of geese have been marked with leg bands, facilitating the detection of movement between colonies.

The Lesser Snow Goose is dichromatic, comprising blue and white (snow) phases; this dichromatism is controlled by a single gene or tightly linked group of genes (Cooke and Mirsky 1972). In this paper the names Lesser Snow Goose or Snow Goose will be used to denote the species, and blue and white to denote the color phases. The ratios of blue to white phase individuals differ significantly from colony to colony and have changed within colonies in the recent past (Cooch 1963). A westward spread of the blue phase led Cooch to postulate some exchange between colonies. The lack of morphological differentiation between Lesser Snow Geese from different colonies (in contrast to that of Canada Geese (Branta canadensis) nesting in the same region that show significant regional morphological variation (MacInnes 1966)) is consistent with the considerable gene exchange between different Snow Goose colonies.

The two color phases mate assortatively (Cooch and Beardmore 1959). Cooke and Cooch (1968), on the basis of a genetic analysis of the Boas River colony, postulated that individuals select mates according to the color phase of their parents. Mate selection might be modified by the relative availability of each color phase at the time of mate selection. Lemieux and Heyland (1967) and Cooch (1961) showed that white phase birds from the Koukdjuak and Boas River colonies, respectively, tended to have a more westerly fall migration route and wintering range than blue phase birds from the same colonies, although separation was far from absolute. This phenomenon is hereafter referred to as differential phase migration. The migration and wintering distributions of the two colonies shared large areas of overlap, indicating that birds from at least two colonies mixed at this time. If pair formation occurred during this period, interchange between colonies would result unless the geese possessed a special means of recognizing birds from their own colony or unless birds from a single colony maintained exclusive flocks.

The purpose of this paper is to determine the amount of gene flow 


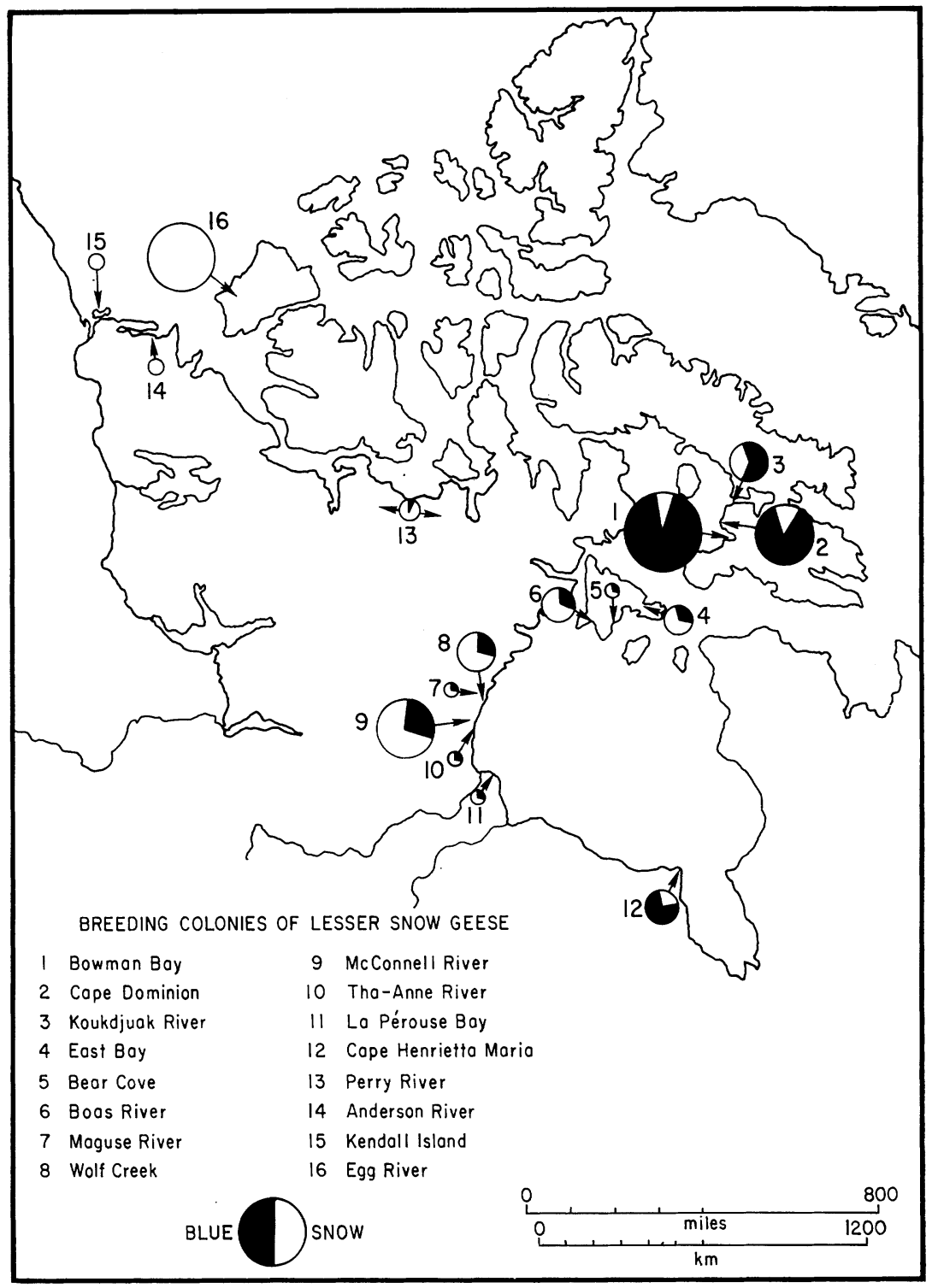

Fig. 1. Showing the distribution, approximate size and phase ratio of all the major ( $>1000$ birds) Lesser Snow Goose breeding colonies in North America. The area of the circles indicates relative size of the colonies, with the smallest circles representing colonies with 5000 breeding birds. The numbers of birds in the larger colonies are extremely difficult to estimate (modified from Dzubin et al. 1974). 
between the different breeding colonies and the extent to which Lesser Snow Goose breeding colonies can be considered as discrete breeding units. To accomplish this we shall examine: (1) the phase ratios of Hudson Bay Lesser Snow Goose populations in breeding and wintering grounds and the relationship between the two, (2) the effects of differential phase migration and the resulting intermingling of geese from different colonies on mate selection and assortative mating, and (3) the extent to which geese return to their natal colony or emigrate to another.

\section{Breeding Colony Distribution}

An excellent summary of the proportions of blue and white phase Lesser Snow Geese at the various breeding colonies up to 1963 is given by Cooch (1963). Dzubin et al. (1975) brought this information up to date and tried to assess the size of the various breeding colonies. Fig. 1 summarizes the more recent information and shows the distribution of all Lesser Snow Goose colonies in North America. Occasional nestings and colonies containing fewer than 1000 birds have been excluded. From the map we see that the western colonies are essentially monochromatic and the colonies surrounding the Hudson Bay drainage are dichromatic. With a few exceptions blue phase frequency is higher in the east.

Cooch (1963) showed that blue phase geese were increasing in all colonies where estimates of phase ratio were made for more than a single season, and on the basis of these estimates he predicted that if present conditions prevailed, most Hudson Bay colonies would exceed $75 \%$ blue phase by 1980. The predicted rate of increase has not occurred, and present ratios at McConnell River are similar to those described prior to 1963. Phase ratio counts from the La Pérouse Bay, Manitoba colony from 1968 through 1972 have revealed no changes in the color composition (Table 1). Phase ratios from McConnell River, collected by several techniques, showed significant differences between years (Table 1), yet no orderly pattern of change, as Cooch (1963) suggested, was evident. These differences could reflect the methods of collecting the data or may indicate real fluctuations in phase ratio.

To summarize, at the present time, white phase birds predominate in the westerly parts of the breeding range, and blue birds in the east. Almost all the birds breeding in the Hudson Bay drainage migrate down the Mississippi and Central Flyways and winter along the Gulf Coast in Texas and Louisiana.

\section{Wintering Ground Distribution}

Cooch (1961) indicated that the discrete breeding colonies had relatively distinct migration routes and wintering grounds. When Cooch 
TABLE 1

Phase Ratios, Pair Bonds, and Population Sizes of Two Hudson Bay Lesser SNow Goose Colonies ${ }^{1}$

\begin{tabular}{|c|c|c|c|c|c|}
\hline $\begin{array}{l}\text { Location } \\
\text { and year }\end{array}$ & $\begin{array}{l}\text { White } \\
\text { pairs }\end{array}$ & $\begin{array}{l}\text { Mixed } \\
\text { pairs }\end{array}$ & $\begin{array}{l}\text { Blue } \\
\text { pairs }\end{array}$ & $\begin{array}{l}\% \text { Blue } \\
\text { phase }\end{array}$ & $\begin{array}{l}\text { Total breeding } \\
\text { pairs }\end{array}$ \\
\hline \multicolumn{6}{|c|}{ La Pérouse Bay } \\
\hline $\begin{array}{l}1968 \\
1969 \\
1970 \\
1971 \\
1972\end{array}$ & $\begin{array}{l}242 \\
439 \\
619 \\
411 \\
850\end{array}$ & $\begin{array}{r}73 \\
91 \\
147 \\
91 \\
205\end{array}$ & $\begin{array}{r}70 \\
98 \\
162 \\
102 \\
231\end{array}$ & $\begin{array}{l}28 \\
23 \\
25 \\
24 \\
26\end{array}$ & $\begin{array}{l}1200 \pm 200 \\
1960 \pm 100 \\
2500 \pm 300 \\
1500 \pm 500 \\
2500 \pm 500\end{array}$ \\
\hline \multicolumn{6}{|c|}{ McConnell River } \\
\hline $\begin{array}{l}1964 \\
1965 \\
1966 \\
1967 \\
1968 \\
1969 \\
1970 \\
1981\end{array}$ & $\begin{array}{c}126 \\
354 \\
270 \\
384 \\
5269^{3} \\
1007 \\
231 \\
145\end{array}$ & $\begin{array}{r}25 \\
59 \\
49 \\
91 \\
165 \\
45 \\
32\end{array}$ & $\begin{array}{c}41 \\
102 \\
96 \\
86 \\
2050^{3} \\
273 \\
44 \\
38\end{array}$ & $\begin{array}{l}28 \\
26 \\
29 \\
23 \\
28 \\
25 \\
21 \\
25\end{array}$ & $\begin{array}{r}\frac{-}{\bar{Z}} \\
43,000^{2} \\
\frac{-}{-} \\
75,000^{2} \\
92,000^{2}\end{array}$ \\
\hline
\end{tabular}

carried out his studies, Snow Geese did not regularly stop over in the Dakotas and Missouri. They do so annually now, and this may result in a greater mixing of colonies than occurred previously. In recent years banding of Lesser Snow Geese has intensified, and samples of birds have been banded from most of the colonies in the Hudson Bay drainage. We have analyzed some of these band recoveries in terms of the numbers of each phase that have been recovered along the traditional Gulf coast wintering grounds, defined as $25^{\circ} 00^{\prime}$ through $30^{\circ} 59^{\prime} \mathrm{N}$ and $85^{\circ} 00^{\prime}$ through $98^{\circ} 59^{\prime} \mathrm{W}$. All direct recoveries (recovered between the time of banding and the end of the following hunting season) were combined for this analysis. Table 2 shows the number of geese from each breeding colony reported recovered and their phase ratio for each degree block of the Gulf coast wintering range. For several reasons this table does not necessarily indicate the actual phase ratio or the relative numbers of Snow Geese using these areas.

Two features stand out. First the winter range of each breeding colony extends over a considerable expanse of the Gulf coast, and the range of each breeding colony overlaps with that of every other colony. Secondly as a result of differential phase migration from each breeding colony, the white phase birds have a more westerly wintering distribution than do the blue phase birds. Thus although clines in the phase ratios 


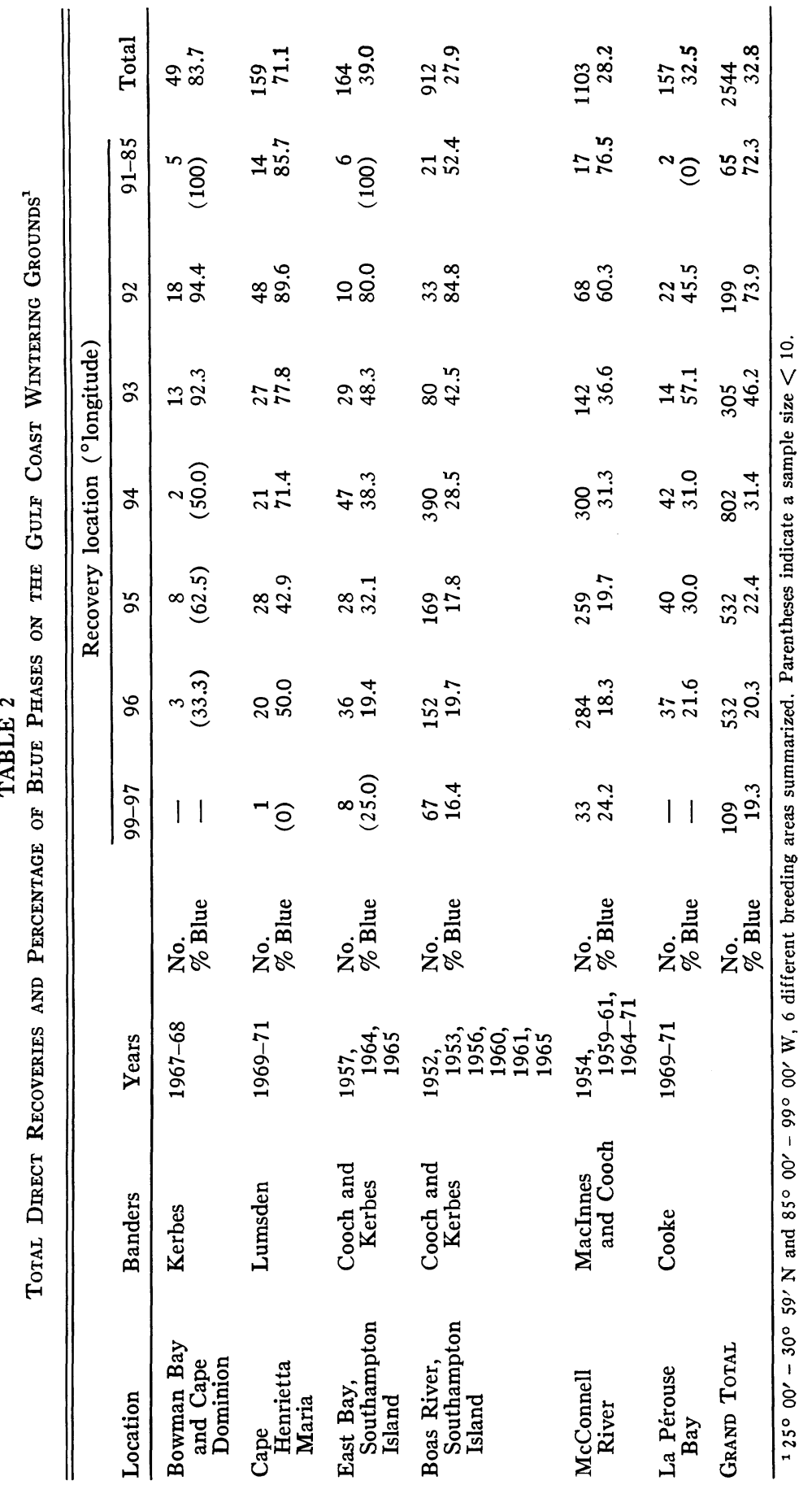


exist in both breeding grounds and wintering grounds, geese cannot be identified as to colony or origin by the phase ratios in winter flocks.

Two explanations of differential phase migration have been proposed. Lemieux and Heyland (1967) suggested that the two color phases are distinct species and thus one might expect their migration routes to be different. Cooch (1958), on the other hand, felt that "like attracts like" in that geese of each color phase would tend to join flocks comprising birds predominantly of their own color. The development of concepts concerning the role of early learning (Cooke and Cooch 1968) would modify this theory to suggest that individuals associated with geese of a color similar to their parents and/or siblings. Because few biologists today would agree that the two color phases are distinct species, we prefer Cooch's theory, although it too may not be the total explanation.

Cooke et al. (1972) showed that young birds in a captive situation will run to an unknown bird of a color phase similar to that of their parent. This could provide a mechanism whereby blue phase birds from western Hudson Bay (predominantly white phase), if they had blue phase parents, could become associated during migration and on the wintering grounds with birds from the predominantly blue phased easterly colonies. Reciprocally, it could explain the association of white phase birds from easterly colonies with birds from the predominantly white phase western colonies.

\section{PAir Formation}

Because the winter ranges of the various Hudson Bay Lesser Snow Goose colonies overlap, possibly more interchange exists between the breeding colonies than was hitherto suspected. If pair formation always or usually occurred between birds from the same breeding colony, then the genetic integrity of the breeding colonies would be maintained even though birds mixed with birds from different colonies on the wintering grounds. This could be achieved, for instance, if pairing occurred in the summer months. Cooch (1958) theorized that first pairing occurred while the 2-year-old subadults congregated around the periphery of the breeding colony in associations of nonbreeders.

Observations of yearling Snow Geese marked with individually coded neck collars at the McConnell River (MacInnes et al. 1969) revealed no evidence of pairing at this time. During late winter and while on spring migration, some of these same birds (now 17-18 months of age) were seen engaged in pairing activity (Prevett 1972). Geese from McConnell River were also mixed during spring migration with Snow Geese from other colonies. Hence pairing seems to occur before the nesting season at a time when geese from several colonies are freely 
intermingled. Still the possibility cannot be excluded that these pairs represent resumptions of associations originally formed in the preceding summer, though this is not supported by observations of marked geese. Also, in a captive flock of Snow Geese at the Niska Waterfowl Research Centre, Guelph, Ontario, the pairing of 2-year-old birds occurred in early March and the pairing did not reflect earlier latent pairings, at least insofar as one could detect by a nearest neighbor analysis (Cooke and McNally 1975) that measured the frequency with which particular birds associated in the summer before visible pair formation occurred.

If pair formation does indeed occur when birds from different breeding colonies are associating, it does not necessarily follow that geese from different colonies pair with one another. Geese from a single colony might associate in exclusive flocks that would not be detectable at the level of the $1^{\circ}$ longitude block. Sightings of neck-collared birds from the McConnell River during migration and on the wintering ground showed no evidence of segregation; marked geese were present in nearly all large flocks encountered between $92^{\circ} 30^{\prime}$ and $97^{\circ} 30^{\prime} \mathrm{W}$ along the Gulf coast. Even if there were true mixing of different colonies when pair formation occurs, mechanisms might exist permitting birds to recognize and pair only with birds from their own breeding colony. They might perhaps respond to auditory or visual cues undetectable by man.

Pair bonds in Lesser Snow Geese persist over several years. Prevett (1972) found no case of a neck-banded adult paired with a new bird while its mate was known to be still alive. He also showed that if one member of a pair died, the survivor re-paired.

\section{COLONY INTEGRITY}

Although banding has been carried out in most Snow Goose breeding colonies around Hudson Bay, direct quantitative information on the amount of genetic exchange between colonies, measured by recapture of banded geese at different colonies is very difficult to obtain. Most bandings at different colonies have not been coincident, so detection of two-way interchange was not always possible. Nonetheless Table 3 shows interchange occurred in most cases where it could have been detected.

We have color marked and banded Lesser Snow Geese with standard aluminum leg bands at McConnell River since 1966 and at La Pérouse Bay since 1969. The return of banded birds to the colonies in subsequent years has been assayed in two ways, first by analyzing the previously banded birds captured in mass banding drives of molting geese, and secondly by counting the color-banded geese among nesting birds. The methods complement each other and check against hidden biases. 
TABLE 3

Interchange of Snow Geese Between Breeding Colonies in The Hudson Bay AREA

\begin{tabular}{lccccccccc}
\hline \hline & \multirow{2}{*}{$\begin{array}{c}\text { Colony } \\
\text { Banded at }\end{array}$} & No. & 1 & 2 & 3 & 4 & 5 & 6 & 7 \\
\cline { 2 - 9 } & Koukjauk River and & 1 & - & + & + & + & + & + & + \\
$\quad$ Cape Dominion & & & & & & & & & \\
Bowman Bay & 2 & + & $\bar{O}$ & $\times$ & $\times$ & + & + & + \\
East Bay & 3 & + & + & + & + & + & + \\
Boas River & 4 & + & + & + & + & + & + & $\bigcirc$ \\
McConnell River & 5 & + & + & + & + & + & + & + \\
La Pérouse Bay & 6 & $\times$ & $\times$ & $\times$ & $\times$ & + & + & + \\
Cape Henrietta Maria & 7 & $\times$ & $\times$ & $\times$ & $\times$ & + & + & - \\
\hline
\end{tabular}

${ }^{1}$ Total geese banded in one colony and recaptured in another: 94 adults and 43 banded as goslings. $+=$ movement is known to have occurred through recapture of geese banded at a different colony; $O^{+}=$no movement was detected; $X=$ movement could not have been detected.

In terms of colony integrity, figures on the rate of return of goslings to the breeding colony are of particular interest. Table 4 shows the number of birds of each sex that were banded as goslings and seen in subsequent years at the La Pérouse Bay and McConnell River colonies. In contrast to the large proportion of female goslings returning to breed, very few males returned to their natal colony. The rate of return remained low for males up to 5 years of age, the oldest birds of known age and sex for which banded samples were available; 16 females 3 years old, caught in 1972 at La Pérouse Bay, represent $5.6 \%$ of the female goslings banded there in 1969. As approximately $25 \%$ of the adults present in the colony in 1972 were caught in the banding drives, this suggests that about $22 \%(5.6 \% \times 4)$ of the female goslings banded in 1969 were breeding at La Pérouse Bay in 1972. This calculation is admittedly crude, but it does indicate that a large proportion of those female goslings hatched at La Pérouse Bay, and that were still alive 3 years later, were present and breeding in their natal colony.

A number of explanations for the lower return of males are possible: (1) differential loss of bands by male and female, (2) differential mortality of male and female, (3) later nesting of males, (4) bias in sampling techniques, or (5) emigration of males from natal colony. Explanation (1) can be eliminated readily. Aluminum band loss is low at least for the first 5 years for all species examined (Hickey 1952). Mortality figures for goslings based on hunter kills are given in Table 5 . The frequencies of males and females shot show no significant differences. Other forms of mortality are more difficult to assess. Most dead adult birds found at the breeding colony are females, but total numbers are low.

Cooch (1958) believed that males nested for the first time when 3 years old, whereas females could nest at 2 years of age. Because the relative 
TABLE 4

Sex of Birds Banded as Goslings Returning to Their Natal Colony at la Pérouse Bay and McConnell River

\begin{tabular}{|c|c|c|c|c|c|}
\hline \multirow{2}{*}{$\underset{\text { detected }}{\text { How }}$} & \multirow{2}{*}{$\underset{\text { (years) }}{\text { Age }}$} & \multicolumn{2}{|c|}{ La Pérouse Bay } & \multicolumn{2}{|c|}{ McConnell River } \\
\hline & & Female & Male & Female & Male \\
\hline \multirow[t]{5}{*}{ Retrapped } & 1 & 19 & 23 & $-^{1}$ & - \\
\hline & 2 & 51 & 1 & 10 & 0 \\
\hline & 3 & 84 & 1 & 27 & 3 \\
\hline & 4 & 17 & - & 16 & 1 \\
\hline & 5 & - & - & 10 & 2 \\
\hline \multirow[t]{4}{*}{ Seen nesting } & 1 & 0 & 0 & 0 & 0 \\
\hline & 2 & 54 & 4 & 25 & 4 \\
\hline & 3 & 18 & 2 & 26 & 4 \\
\hline & 4 & - & - & 12 & 2 \\
\hline \multirow{4}{*}{$\begin{array}{l}\text { Seen, } \\
\text { not nesting }\end{array}$} & 1 & $-^{2}$ & - & -3 & - \\
\hline & 2 & - & - & 39 & 14 \\
\hline & 3 & - & - & 11 & 5 \\
\hline & 4 & - & - & 1 & 0 \\
\hline
\end{tabular}

${ }^{1}$ Banding drives at McConnell River were not designed to catch nonbreeding geese that molt earlier in flocks largely segregated from breeders at this colony. Nonbreeders associated with breeders more commonly at La Pérouse Bay.

${ }^{2}$ Nonbreeding geese at $\mathrm{La}$ Pérouse Bay were not studied.

${ }^{3}$ Sex of yearlings observed at McConnell River was not determined.

numbers of males in the 2-, 3-, 4-, and 5-year-old age classes did not change, and as the sex ratio of breeding and nonbreeding 2- and 3-yearolds was similar $(0.05<\mathrm{p}<0.10)$, the probability that males return to their natal colony but at a more advanced age is remote. By analogy with what is known of other geese (e.g. Bauer and Glutz 1968), that most males delay nesting until they are more than 5 years old seems inconceivable. Our data show that 2-year-old males can breed.

Bias in sampling is unlikely to explain the discrepancies. Because two distinct methods were used to collect the data and they agree so well, we feel that the difference in return rate between the sexes is real. The sex ratio of birds in the banding drives is approximately $1: 1$, and we have noted no obvious surplus of either sex on the breeding colony.

As the above hypotheses are unlikely, the most plausible explanation for the disappearance of banded male goslings from the breeding colonies is emigration. Because there are equal numbers of each sex in the breeding population, one must infer that there has been compensating immigration of males from other colonies. Direct evidence of immigration is difficult to obtain because much of the arctic banding has concentrated on banding as many birds as possible, and consequently the sexes were usually not determined. Four birds of known sex banded as goslings have been recaptured in different colonies 2 or more years later and three of these were males. 
TABLE 5

Proportion of Male and Female Snow Geese Banded as Goslings

\begin{tabular}{llcccc}
\hline \hline Colony & Sex & $\begin{array}{c}\text { Number } \\
\text { banded }\end{array}$ & $\begin{array}{c}\text { Reported } \\
\text { shot }\end{array}$ & $\%$ & \\
\hline La Pérouse Bay & Male & 2103 & 204 & 9.7 & $\mathrm{p}>0.10$ \\
$1969-1971$ & Female & 2127 & 192 & 9.0 & \\
& & & & & $\mathrm{p}>0.10$ \\
McConnell $_{\text {River }}{ }^{1968}$ & Male & 1797 & 303 & 16.9 & \\
$1966-1968$ & Female & 1816 & 301 & 16.6 & \\
\hline
\end{tabular}

1 Just direct recoveries.

2 Includes indirect recoveries up to 1971.

It seems that females hatched in a particular colony generally will return to that colony for at least the first nesting, but that the males do so only rarely. This suggests strongly that pair formation does not usually occur between members of the same breeding colony, and implies that mate selection probably occurs outside the breeding season, when birds from different colonies are associating. A further conclusion is that when two birds from different colonies pair, the female determines the colony in which the pair will nest.

The phenomenon of differential return to the breeding colony is not restricted to birds banded as goslings. Table 6 shows the numbers and sexes of geese banded as adults at McConnell River and at La Pérouse Bay that were subsequently retrapped at those colonies. The proportion of males among the retrapped birds decreases progressively. Adult females from McConnell River were more vulnerable to hunting than males. Of 974 adult females 189 (19.4\%) banded in the years 1966 through 1968 were subsequently reported shot as against only 173 of 1139 adult males $(15.2 \%)$. This difference is significant at the $5 \%$ level, which makes the preponderance of females retrapped in later years even more meaningful. At La Pérouse Bay the sexes do not differ significantly in numbers reported shot.

More data on the same phenomenon came from visual sightings during the periods of incubation and hatch of mated pairs marked with colored leg bands (La Pérouse Bay) or neck collars (McConnell River) (Table 7). Banding drives (Cooch 1956) were designed to catch flocks composed of adult pairs and their goslings. Every adult was not always caught and some pairs had just one banded bird. As almost equal numbers of males and females were banded at each location, these pairs should have contained equal numbers of banded males and females. Recapture in subsequent years, however, shows a large excess of pairs where only the female was banded. The excess was greater in the second 
TABLE 6

Sex Ratio of Adults Banded and Subsequently Recaptured at McConnell River and La Pérouse Bay

\begin{tabular}{|c|c|c|c|c|c|c|c|}
\hline \multirow{3}{*}{$\begin{array}{l}\text { Banded } \\
\text { at }\end{array}$} & \multirow[b]{3}{*}{ Year } & \multirow{2}{*}{\multicolumn{3}{|c|}{ Number banded }} & \multicolumn{3}{|c|}{ Number captured } \\
\hline & & & & & \multirow[b]{2}{*}{ Female } & \multirow[b]{2}{*}{ Male } & \multirow{2}{*}{$\begin{array}{r}\% \\
\text { Male }\end{array}$} \\
\hline & & Female & Male & $\%$ Male & & & \\
\hline \multirow{3}{*}{$\begin{array}{l}\text { McConnell } \\
\text { River }\end{array}$} & 1966 & 261 & 280 & 52 & 46 & 22 & $32^{1}$ \\
\hline & 1967 & 417 & 593 & 59 & 34 & 28 & $45^{2}$ \\
\hline & 1968 & 296 & 266 & 47 & 20 & 11 & 35 \\
\hline \multicolumn{2}{|l|}{ Total } & 974 & 1139 & 54 & 100 & 61 & $38^{1}$ \\
\hline \multirow{3}{*}{$\begin{array}{l}\text { La Pérouse } \\
\text { Bay }\end{array}$} & 1969 & 45 & 28 & 38 & 17 & 5 & 23 \\
\hline & 1970 & 539 & 504 & 48 & 149 & 99 & $40^{1}$ \\
\hline & 1971 & 275 & 286 & 51 & 55 & 42 & 43 \\
\hline \multicolumn{2}{|l|}{ Total } & 859 & 818 & 49 & 221 & 146 & $41^{1}$ \\
\hline
\end{tabular}

${ }^{1} \mathrm{p}<0.05$

$2 \mathrm{p}<0.01$

and subsequent years than in the year immediately following banding, indicating a continuing disappearance of marked males.

The data in Table 7 therefore strongly suggest a loss of male birds among previously mated pairs. As male mortality is not substantially higher than female mortality, at least as evidenced by reported hunter kills, the greater loss of males among previously mated pairs suggests that some of the males that did not return to the colony where banded are still alive and breeding elsewhere.

A working hypothesis to explain the greater loss of adult males is as follows: when a pair is broken (usually by death of one member), a new mate is acquired. A female will return with her new mate to the colony in which she nested the previous year; a male will accompany his new mate to where she previously nested. Because La Pérouse Bay is a small colony and pair formation takes places in flocks of mixed origin, the probability of a La Pérouse Bay female choosing a new mate from her own colony is small. Consequently if a male dies, he is lost to the breeding colony but his mate is not, whereas if a female dies both birds are usually lost to the breeding colony. If the chance of death of one member of a pair were independent of the death of the other (this is unlikely to be strictly true), then the rate of return of males to the colony would be the square of the return of the females. This relationship assumes that the size of the colony is small relative to the size of the total Hudson Bay population.

The McConnell River colony is much larger than that at La Pérouse Bay, and hence more widowed males from this colony could be expected to remate with McConnell River geese. This expectation is borne out 
TABLE 7

Pairs of Snow Geese Banded as Adults and Found Nesting in Subsequent Years at Colony Where Banded

\begin{tabular}{|c|c|c|c|c|c|c|c|}
\hline \multicolumn{2}{|c|}{ Year banded } & \multirow{2}{*}{\multicolumn{6}{|c|}{ Sighted in subsequent years }} \\
\hline \multirow{2}{*}{$\begin{array}{c}\text { Mc- } \\
\text { Connell } \\
\text { River }\end{array}$} & \multirow{2}{*}{$\begin{array}{c}\mathrm{La} \\
\text { Pérouse } \\
\text { Bay }\end{array}$} & & & & & & \\
\hline & & $\begin{array}{c}\text { Both } \\
\text { banded }\end{array}$ & $\begin{array}{l}\text { Only } 9 \\
\text { banded }\end{array}$ & 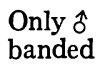 & $\begin{array}{c}\text { Both } \\
\text { banded }\end{array}$ & $\begin{array}{l}\text { Only } 9 \\
\text { banded }\end{array}$ & $\begin{array}{l}\text { Only } \hat{0} \\
\text { banded }\end{array}$ \\
\hline & & \multicolumn{3}{|c|}{1 year later } & \multicolumn{3}{|c|}{2 years later } \\
\hline 1966 & - & 11 & 19 & 18 & 6 & 14 & 4 \\
\hline 1967 & - & 30 & 5 & 14 & 10 & 18 & 8 \\
\hline 1968 & - & 74 & 18 & 6 & 15 & 29 & 4 \\
\hline 1969 & - & 54 & 25 & 10 & - & - & - \\
\hline Total & & & 67 & $\begin{array}{l}48 \\
(42 \%)\end{array}$ & & 61 & $\begin{array}{l}16 \\
(21 \%)\end{array}$ \\
\hline- & 1970 & - & - & - & 58 & 43 & 3 \\
\hline- & 1971 & 58 & 23 & 5 & 41 & 30 & 2 \\
\hline- & 1972 & 73 & 66 & 15 & & & \\
\hline \multirow[t]{2}{*}{ Total } & & & 89 & $\begin{array}{l}20 \\
(18 \%)\end{array}$ & & 73 & $\begin{array}{l}5 \\
(6 \%)\end{array}$ \\
\hline & & \multicolumn{3}{|c|}{3 years later } & \multicolumn{3}{|c|}{4 years later } \\
\hline 1966 & - & 5 & 10 & 7 & 2 & 16 & 2 \\
\hline 1967 & - & 1 & 14 & 7 & - & - & - \\
\hline Total & & & 24 & $\begin{array}{l}14 \\
(37 \%)\end{array}$ & & 16 & $\stackrel{2}{(11 \%)}$ \\
\hline - & 1970 & 44 & 60 & 3 & & & \\
\hline Total & & & 60 & $\stackrel{3}{(5 \%)}$ & & & \\
\hline
\end{tabular}

by the data in Table 7. A higher proportion of pairs containing just color marked males was found at McConnell River than at La Pérouse Bay 1 and 2 years after banding $(\mathrm{p}<0.05)$.

If one makes a few simplifying assumptions, the relative rate of male and female return to nesting colony can be formulated mathematically for any size of colony. Assume that if a female survives between breeding seasons she will return to the breeding colony. Assume also that if death of one member of a pair occurs, a new pair will be formed.

Let $\mathrm{p}=$ probability of male survival $=$ probability of female survival.

$\mathrm{N}_{\mathrm{c}}=$ number of birds from particular breeding colony where mate selection is occurring.

$\mathrm{N}_{\mathrm{T}}=$ total number of birds where mate selection is occurring.

Return of females is by our simplifying assumption $p$.

A male will return if: 
(1) both he and his mate survive; probability $=\mathrm{p} \times \mathrm{p}=\mathrm{p}^{2}$

(2) his mate is killed $(1-p)$ but he survives ( $p$ ) and pairs with another bird from the same breeding colony as his former mate;

$$
\text { probability }=\left(\frac{\mathrm{N}_{\mathrm{c}}}{\mathrm{N}_{\mathrm{T}}}\right)\left(\mathrm{p}-\mathrm{p}^{2}\right)
$$

Return of males is then:

$$
\mathrm{p}^{2}+\left(\frac{\mathrm{N}_{\mathrm{c}}}{\mathrm{N}_{\mathrm{T}}}\right) \mathrm{p}-\left(\frac{\mathrm{N}_{\mathrm{c}}}{\mathrm{N}_{\mathrm{T}}}\right) \mathrm{p}^{2}
$$

If the colony number were small relative to the size of $\mathrm{N}_{\mathrm{T}}$ :

$$
\mathrm{N}_{\mathrm{c}} \ll \mathrm{N}_{\mathrm{T}} ; \quad \mathrm{p}^{2}+\left(\frac{\mathrm{N}_{\mathrm{c}}}{\mathrm{N}_{\mathrm{T}}}\right) \mathrm{p}-\left(\frac{\mathrm{N}_{\mathrm{c}}}{\mathrm{N}_{\mathrm{T}}}\right) \mathrm{p}^{2} \bumpeq \mathrm{p}^{2}
$$

If $\mathrm{N}_{\mathrm{c}}$ were very large relative to $\mathrm{N}_{\mathrm{T}} ; \mathrm{N}_{\mathrm{c}} \bumpeq \mathrm{N}_{\mathrm{T}}$ :

$$
\mathrm{p}^{2}+\left(\frac{\mathrm{N}_{\mathrm{c}}}{\mathrm{N}_{\mathrm{T}}}\right) \mathrm{p}-\left(\frac{\mathrm{N}_{\mathrm{c}}}{\mathrm{N}_{\mathrm{T}}}\right) \mathrm{p}^{2} \bumpeq \mathrm{p}
$$

This formula can be refined as more is learned about the validity of the assumptions made.

As an example of how this formula can be used, if a sample of breeding adult geese were marked at a small breeding colony such that $\mathrm{N}_{\mathrm{c}} \ll$ $\mathbf{N}_{T}$, the proportion of marked geese still nesting at the colony in the $t^{\text {th }}$ year after marking would be approximately $\mathrm{p}^{\mathrm{t}}$ for females and $\mathrm{p}^{2 \mathrm{t}}$ for males, where $p$ is the annual survival rate. It must be remembered that it is assumed that all surviving female geese return to the breeding colony and that all geese that lose their mates pair again. As neither of these assumptions is strictly correct, $p$ represents a minimal estimate of survival. In Table 8 the percentage of male and females remaining on the breeding colony after a number of years has been calculated theoretically on the assumption of $p=0.75$ and from actual data from the La Pérouse Bay colony based on birds banded in 1970 and 1971 and resighted nesting on the colony in 1972 and 1973 . The percentages were calculated from counts of a large proportion of the nesting birds (30-50\%), assuming that they represented a random sample of the colony, and extrapolating from the number of birds seen carrying bands of the particular year class to estimate the total number of birds nesting on the colony.

Although the evidence given so far shows that exchange between colonies is much more prevalent in the males, we have some direct evidence that females also occasionally move from one colony to another. Three breeding females banded at McConnell River were found nesting at La Pérouse Bay in 1972, and another female nested at McConnell River and Bowman Bay in successive years. Two adult females 
TABLE 8

Percentage of Male and Female Adult Geese from a Marked Sample Still Present at a Breeding Colony in Subsequent Years

\begin{tabular}{|c|c|c|c|c|c|c|}
\hline & Sex & 0 & 1 & 2 & 3 & 4 \\
\hline \multicolumn{7}{|c|}{ Theoretical example $(\mathrm{p}=0.75)$ : } \\
\hline & $\begin{array}{l}\text { Female } \\
\text { Male }\end{array}$ & $\begin{array}{l}100 \\
100\end{array}$ & $\begin{array}{l}75 \\
56.2\end{array}$ & $\begin{array}{l}56.2 \\
31.6\end{array}$ & $\begin{array}{l}42.1 \\
17.8\end{array}$ & $\begin{array}{l}31.6 \\
10.0\end{array}$ \\
\hline \multicolumn{7}{|c|}{ Percentages observed at La Pérouse Bay: } \\
\hline Banded in 1970 & $\begin{array}{l}\text { Female } \\
\text { Male }\end{array}$ & $\begin{array}{l}100 \\
100\end{array}$ & - & $\begin{array}{l}54 \pm 3 \\
32 \pm 2\end{array}$ & $\begin{array}{l}40 \pm 2 \\
20 \pm 2\end{array}$ & \\
\hline Banded in 1971 & $\begin{array}{l}\text { Female } \\
\text { Male }\end{array}$ & $\begin{array}{l}100 \\
100\end{array}$ & $\begin{array}{l}80 \pm 4 \\
65 \pm 3\end{array}$ & $\begin{array}{l}55 \pm 3 \\
37 \pm 2\end{array}$ & & \\
\hline
\end{tabular}

banded at La Pérouse Bay in 1970 were caught in the banding drives at McConnell River in 1971. Because the La Pérouse Bay colony is on the migration route of birds from McConnell River, it is perhaps not surprising that some exchange of females occurs between the colonies. There seems to be a similar exchange between the Cape Henrietta Maria and Baffin Island colonies.

\section{Discussion}

This discussion is based on four major premises, the evidence for which is given in this or earlier papers.

(1) Mate selection occurs during spring migration or on the wintering ground when birds from several colonies are mixed (this paper).

(2) When birds from different colonies form pairs, each pair return to the female's natal colony to breed (this paper).

(3) Differential phase migration occurs such that white phase birds from each breeding colony have a more westerly fall and winter distribution than blue phase birds (Cooch 1963, Lemieux and Heyland 1967, this paper).

(4) Mate selection in terms of color is determined largely by an early learning process whereby birds select mates of a color phase similar to that of one of their parents (Cooke and Cooch 1968).

In a species such as the Lesser Snow Goose where pair bonds usually last from year to year, the timing and nature of the first pairing is important to an understanding of the genetic integrity of the various breeding colonies. Evidence presented above shows that a large proportion of the female goslings hatched at La Pérouse Bay return to breed at the natal colony. In contrast the return rate of male goslings is extremely low at both colonies investigated. If one analyzes retrap figures only, of those birds banded as goslings and recovered at the natal colony 
2, 3, 4, or 5 years later, 8 were males and 215 were females (Table 4). This strongly suggests that males return to breed in their natal colony only if they happen to pair with a female from the same colony. This appears to be a rare event, although it is more common in the larger colony as would be expected.

Snow Geese and perhaps all geese seem to be similar to many ducks in which pair formation often takes place in winter quarters and during migration (Weller 1965), in that mates are often natives of places remote from each other and usually the male returns with the female to her natal area. Banding returns show that females do not always return to their natal colony to breed, which is consistent with the facts that several new colonies have been established recently and other sites may be used intermittently as breeding grounds (Hanson et al. 1972).

Perhaps the most important feature of these findings is the realization that the amount of interchange of breeding birds between geographically distinct breeding colonies is extremely high. This gene flow is largely a function of the male pattern of dispersion, whereby most males breed in a different colony from the one where they were hatched, but some contribution to gene flow is provided by females that nest in a nonnatal colony. At La Pérouse Bay almost all the males and perhaps some of the females hatched at a different colony. This suggests that approximately $50 \%$ of all the birds breeding for the first time are immigrants, hatched elsewhere. The colony at La Pérouse Bay may have a high immigration and emigration rate in that it is relatively small and is on the migration route of several more northerly colonies.

Birds banded in one colony and recovered in another give information suggesting that although exchange is more frequent between geographically closer colonies, exchange occurs between nearly all colonies, indicating little barrier to gene flow. Restrictions to gene flow do occur as a result of the tendency of females to return to the same colony year after year, and from the fact that pair bonds last for more than one breeding season. Adults also move between colonies, but we have not incorporated this into our calculations of gene flow. The effects of this are at present difficult to assess, but they may be considerable.

With such a large amount of gene flow between the distinct breeding colonies, it is likely that few genetic differences exist between colonies, apart from any genes that may be located on the $\mathrm{W}$ chromosome of the heterogametic female geese. The Hudson Bay and Foxe Basin populations of Snow Geese may be usefully considered as a large interbreeding population that is largely homogeneous in its genetic composition. The lack of morphological differences between birds from these colonies is consistent with this contention. 
The realization that the Hudson Bay population could be considered as one population from the genetic standpoint suggests that genetic differences should not be found between the various colonies. This conclusion is in contradiction to the known facts summarized earlier in the paper regarding frequencies of the gene controlling the color phase. In other words, the one gene frequency whose value is known contradicts the evidence of extensive gene flow in that not all colonies have a similar color phase ratio. How then, assuming a large amount of gene flow, have different colonies been able to maintain their characteristic color phase ratios? Differential phase migration and assortative mating may provide the answer to this paradox. Both these phenomena can be explained on the basis of early learning whereby goslings will usually associate with and later pair with birds of a color phase similar to that of their parents. Mate selection in terms of color depends on preference and prevalence. Birds pairing for the first time not only choose mates according to the color phase of their parents but also, because of differential phase migration, they are located in flocks where that phase predominates. The relative effects of preference and prevalence are at present difficult to assess.

Although genes are able to flow rapidly through the whole population because of the considerable gene flow, apparently the movement of the alleles concerned with color do not result in changes in phase ratio at a colony as the gene frequency (in terms of color) of the birds entering a colony will be determined by the nonimmigrant birds of that colony, which choose the color of their mates. To be more specific, in a hypothetical colony consisting only of white birds that mixed on the wintering ground with blue and white phase birds from several different colonies, the females would choose mainly white mates, and would return to their natal colonies. The immigrant males could be from any of the other colonies, so there would still be considerable gene flow between colonies, but alleles controlling the blue color would rarely enter the colony, thus maintaing the phase ratio in the face of considerable gene flow. The present distribution of the color phases is partly determined by the historical events that led to the origin of the two phases and partly by the traditions (of mate selection and migration) that slow down the equilibration of the phase ratios.

\section{ACKNOWLEDGMENTS}

These studies formed part of an investigation being carried out under contract with the Canadian Wildlife Service. Financial assistance was also provided by the National Research Council; the Manitoba Department of Mines, Resources and Environmental Management; the Arctic Institute of North America; and the Canadian National Sportsmen's Show. We also thank T. Bargiello, H. Boyd, P. 
Colgan, G. Finney, R. Rockwell, J. P. Ryder, and W. N. Holsworth for their helpful comments on an earlier draft of this paper.

Considerable logistic help was provided by the personnel of the N.R.C.'s Churchill Research Range. Special thanks are due to Father Lionel Ducharme, O.M.I., and to the personnel of the Department of Indian and Northern Affairs, and the Hudson's Bay Company at Eskimo Point, who went out of their way to help. To the numerous assistants who survived mosquitoes, polar bears, and banding drives we are most grateful. We thank F. G. Cooch, T. W. Barry, H. G. Lumsden, L. Lemieux, and R. H. Kerbes for permission to use their unpublished banding data. The Canadian Wildlife Service, through A. Dzubin, compiled Fig. 1.

\section{Summary}

Color phase ratios of the Hudson Bay and Foxe Basin populations of the Lesser Snow Goose (Chen c. caerulescens) were tabulated on the breeding grounds and wintering areas. Differential phase migration (i.e. the tendency of white phase birds to have a more westerly migration than blue phase birds) occurs, and birds from the different breeding colonies mix considerably on the wintering grounds and in migration.

Returns of banded goslings show that whereas female geese frequently return to the natal colony to breed, males seldom do so. The lack of return of males is attributed to emigration. Most, if not all, pair formation occurs on the wintering grounds and during spring migration, when birds from different breeding colonies are associating. When two birds from different colonies pair, the female usually returns with her mate to her natal colony.

Gene flow per generation at the La Pérouse Bay colony is estimated to be approximately $50 \%$. At larger colonies the value is expected to be somewhat lower. In view of this large gene flow, the Hudson Bay populations of the Lesser Snow Geese perhaps should be considered from the genetic standpoint as a single interbreeding population. In view of this, the differences in color phase ratios at different breeding colonies are puzzling. This paradox can be resolved by assuming that the early learning experience that results in both assortative mating and differential phase migration restricts the rates at which color phase ratios change at the different colonies.

\section{Literature Cited}

Bauer, K. M., and U. N. Glutz von Blutzheim. 1968. Handbuch der Vögel Mitteleuropas. Bds. Anseriformes (1. Teil). Frankfurt am Main, Akademische Verlagsgesellschaft.

Соосн, F. G. 1956. Mass ringing of flightless Blue and Lesser Snow Geese in Canada's eastern arctic. Wildfowl Trust Ann. Rept. 8: 58-67.

Cooch, F. G. 1958. The breeding biology and management of the Blue Goose. Unpublished Ph.D. dissertation, Ithaca, New York, Cornell Univ. 
Cooch, F. G. 1961. Ecological aspects of the Blue-Snow Goose complex. Auk 78: 72-89.

Соoch, F. G. 1963. Recent changes in distribution of color phases of Chen $c$. caerulescens. Proc. 13th Intern. Ornithol. Congr.: 1182-1194.

CoOch, F. G., AND J. A. BEARDMORe. 1959. Assortative mating and reciprocal difference in the Blue-Snow Goose complex. Nature 183: 1833-1834.

Cooke, F., ANd F. G. Coоch. 1968. The genetics of polymorphism in the goose Anser caerulescens. Evolution 22: 289-300.

Cooke, F., AND C. M. MCNally. 1975. Mate selection and color preferences in Lesser Snow Geese. Behaviour, in press.

Cooke, F., AND MIRSky, P. 1972. A genetic analysis of Lesser Snow Goose families. Auk 89: 863-871.

Cooke, F., P. J. Mirsky, ANd M. B. Seiger. 1972. Color preferences in the Lesser Snow Goose and their possible role in mate selection. Canadian J. Zool. 50: $529-536$.

Dzubin, A., H. Boyd, And W. J. D. Stephen. 1975. Blue and Snow Goose distribution in the Mississippi and Central Flyways: a preliminary report. Progr. Notes, Canadian Wildl. Serv., in press.

Hanson, H. C., H. G. Lumsden, J. J. Lynch, and H. W. Norton. 1972. Population characteristics of three mainland colonies of the Blue and Lesser Snow Geese nesting in the southern Hudson Bay region. Res. Rept. (Wildl.) 93, Ontario Min. Nat. Resources.

Hickey, J. J. 1952. Survival studies of banded birds. U. S. Fish Wildl. Serv., Spec. Sci. Rept., Wildl. No. 15.

Lemieux, L., and J. Heyland. 1967. Fall migration of Blue Geese and Lesser Snow Geese from the Koukdjuak River, Baffin Island, Northwest Territories. Natur. Canadien 94: 677-694.

MacInnes, C. D. 1966. Population behavior of eastern arctic Canada Geese. J. Wildl. Mgmt. 30: 536-553.

MacInnes, C. D., J. P. Prevett, And H. A. Edney. 1969. A versatile collar for individual identification of geese. J. Wildl. Mgmt. 33: 330-335.

PrevetT, J. P. 1972. Family behavior and age-dependent breeding biology of the Blue Goose (Anser caerulescens). Unpublished $\mathrm{Ph} . \mathrm{D}$. dissertation, Univ. Western Ontario, London.

Weller, M. W. 1965. Chronology of pair formation in some Nearctic Aythya (Anatidae). Auk 82: 227-235.

Department of Biology, Queen's University, Kingston, Ontario, Canada, and Department of Zoology, University of Western Ontario, London, Ontario, Canada. Present address of second author: Fish and Wildlife Research Branch, Ontario Ministry of Natural Resources, Maple, Ontario, Canada. Present address of third author: District Biologist, Ministry of Natural Resources, Moosonee, Ontario, Canada. Accepted 3 June 1974. 